\title{
Ethnobotanical Research on the Knowledge of Vernonia amygdalina Leaves in the Treatment of Liver Diseases in South Benin
}

\author{
Adjouavi Yvette Deguenon ${ }^{1,5}$, *, Bernadin Manou Elegbede ${ }^{2}$, Théodore Soussia ${ }^{3}$, Kissao Gnandi ${ }^{4}$, \\ Patrick Aleodjrodo Edorh ${ }^{1}$, Guillaume Koffivi Ketoh ${ }^{5}$ \\ ${ }^{1}$ Department of Biochemistry and Cell Biology, Faculty of Science, University of Abomey-Calavi (UAC), Godomey, Benin \\ ${ }^{2}$ National Water Institute, University of Abomey-Calavi (UAC), Godomey, Benin \\ ${ }^{3}$ National Medical and Health Institute, University of Abomey-Calavi (UAC), Godomey, Benin \\ ${ }^{4}$ Department of Geology, Faculty of Science, University of Lome (UL), Lomé, Togo \\ ${ }^{5}$ Department of Physiology/Pharmacology, Faculty of Science, University of Lome (UL), Lomé, Togo
}

Email address:

deguenonyvette01@gmail.com (A. Y. Deguenon), manelegbede@gmail.com (B. M. Elegbede), soussiatheodore@gmail.com (T. Soussia)

${ }^{*}$ Corresponding author

\section{To cite this article:}

Adjouavi Yvette Deguenon, Bernadin Manou Elegbede, Théodore Soussia, Kissao Gnandi, Patrick Aleodjrodo Edorh, Guillaume Koffivi Ketoh. Ethnobotanical Research on the Knowledge of Vernonia amygdalina Leaves in the Treatment of Liver Diseases in South Benin. Journal of Health and Environmental Research. Vol. 6, No. 3, 2020, pp. 44-50. doi: 10.11648/j.jher.20200603.11

Received: May 20, 2020; Accepted: June 1, 2020; Published: June 9, 2020

\begin{abstract}
Most of the inhabitants of South Benin use medicinal plants to treat various pathologies. Several research studies have cited Vernonia amygdalina as a hepatoprotective medicinal plant. The objective of this work is to list the medicinal plants made available to the population to treat liver diseases by herbalists and to verify their level of knowledge in relation to the use of Vernonia amygdalina. The methodology consists of conducting a semi-structured survey of herbalists in markets, on sites where medicinal plants are sold and in households. This methodology allowed us to identify 38 species of medicinal plants belonging to 20 families. The best represented species is Bridelia ferruginea (10) of the family Euphobiaceae. The Rubiaceae family is the most represented (16). The organ of the plant most frequently used in recipes is the root (47). Five hundred and fifty-two households (552) responded to our questions. 64\% use the leaves of Vernonia amygdalina for nutrition against $36 \%$ for therapeutic use. $68 \%$ are supplied from distant fields, $13 \%$ from urban areas and 19\% from market gardening sites. 35\% say they have no information about its use in phytotherapy, $21 \%$ use it for intestinal ailments, $18 \%$ for the treatment of malaria, $13 \%$ for oral diseases, $12 \%$ for other pathologies. The frequency of use (four times a week) is best represented for nutrition and phytotherapy. In conclusion, Vernonia amygdalina is very little known in phytotherapy despite the various researches carried out on this plant. Researchers must promote medicinal plants that are very easy to grow in order to limit the offer to users of rare plants in danger of extinction.
\end{abstract}

Keywords: Vernonia amygdalina, Ethnobotanical Investigation, Liver Diseases

\section{Introduction}

Liver disease is a public health problem in Benin today. Hepatitis B virus and chronic alcoholism are the primary cause of cirrhosis and hepatocellular carcinoma [1]. Chronic exposures to drugs and toxic products go unnoticed among the causes of hepatitis. Many scientific studies have shown that several drugs and toxic products induce hepatitis [2, 3].
With environmental degradation and the introduction of new cultivation methods based on the massive use of agricultural inputs, the population is inevitably chronically exposed to hepatotoxics. In Benin, traditional therapists and herbalists are the first people to receive the disease in most cases [4]. The latter provide the patient with a number of medicinal plants to address their health problem $[5,6]$. The recipes made available to patients are multiple and vary from one 
traditional therapist, one herbalist to another. All plant organs are offered: root, stem, leaves, bark and the whole plant. These proposals do not guarantee the conservation of the flora because in the majority of the recipes proposed for the treatment of pathologies, the roots and barks occupy a significant proportion. Instead of the rare species, other fast growing and easy to grow plants can be proposed in order to protect the environment. Scientific work has shown that Vernonia Amygdalina is very effective in the treatment of liver diseases [7-9]. Vernonia Amygdalina, is a medicinal plant used in nutrition and phytotherapy [10-12]. An ethnobotanical survey allows us to list the medicinal plants made available to patients suffering from this liver disease and to verify the level of knowledge of the population of South Benin on the different uses made of this nutritional and therapeutic plant.

\section{Materials and Methods}

\subsection{Study Sites}

\subsubsection{Cotonou Site}

The commune of Cotonou is located on the barrier beach that stretches between Lake Nokoué and the Atlantic Ocean, made up of alluvial sands with a maximum height of about five metres. Its geographical coordinates are: latitude $6^{\circ} 21^{\prime} 55$ $\mathrm{N}$; longitude $2^{\circ} 25^{\prime} 5 \mathrm{E}$ with an altitude of $7 \mathrm{~m}$ above sea level. It is bounded to the north by the municipality of Sô-Ava and Lake Nokoué, to the south by the Atlantic Ocean, to the east by the municipality of Sèmè-Kpodji and to the west by that of Abomey-Calavi. It covers an area of $79 \mathrm{~km}^{2}$. The commune of Cotonou, which is located in the coastal plain, has sandy soils that are generally poor in organic matter. All the districts of Cotonou comprise 154,346 households with a population of 665,100 inhabitants [13].

\subsubsection{Abomey-Calavi Site}

The commune of Abomey Calavi, located in the southern part of the Republic of Benin and the Atlantic Department, is bordered to the north by the commune of Zè, to the south by the Atlantic Ocean, to the east by the communes of Sô-Ava and Cotonou, and to the west by the communes of ToriBossito and Ouidah. Its geographical coordinates are latitude: $6^{\circ} 26^{\prime} 55^{\prime \prime} \mathrm{N}$; longitude $2^{\circ} 21^{\prime} 20^{\prime \prime} \mathrm{E}$ with an altitude of $11 \mathrm{~m}$ above sea level. It covers an area of $539 \mathrm{Km}^{2}$ with 149 villages and city districts. Most of the commune is occupied by tropical ferruginous and sandy soils [14].

\subsubsection{Ouidah Site}

The commune of Ouidah is located between $2^{\circ}$ and $2^{\circ} 15$ East latitude and $6^{\circ} 15$ and $6^{\circ} 30$ in the Atlantic Department. It covers an area of $364 \mathrm{~km}^{2}$ and is bounded to the south by the Atlantic Ocean, to the east by the Commune of AbomeyCalavi, to the west by the Commune of Grand-Popo, and to the north by the Communes of Kpomassè and Tori - Bossito. There are sandy soils, ferralitic soils and sandy soils. The commune registered 76,555 inhabitants in 2002 with 18,958 households [15].

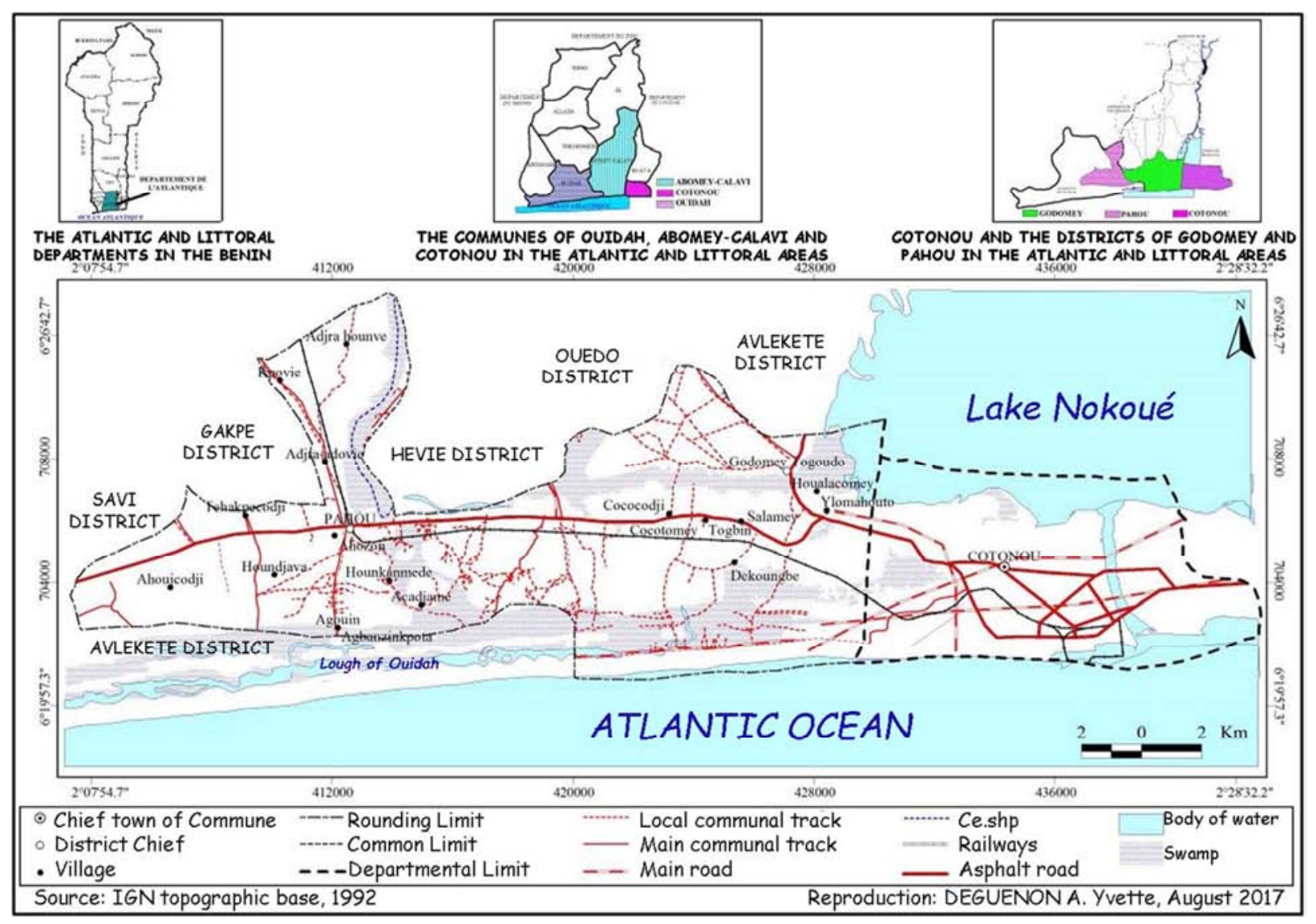

Figure 1. Situation map showing the three communes: Cotonou, Abomey-Calavi and Ouidah. 


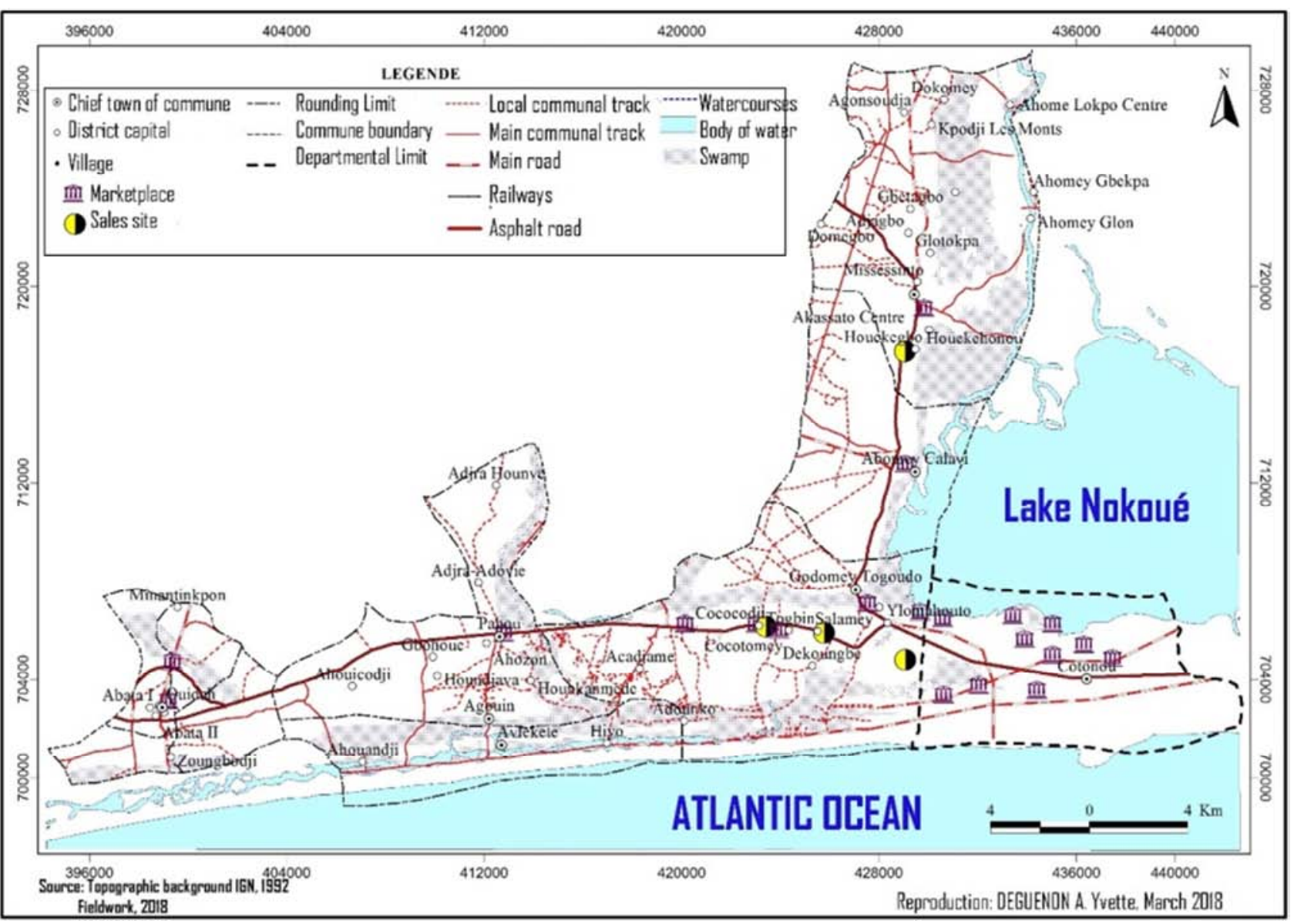

Figure 2. Medicinal plant collection sites and markets.

\subsection{Sampling and Data Collection}

A semi-structured survey among herbalists was carried out in three communes in southern Benin in order to list the medicinal plants available to the population in case of liver diseases. The medicinal plants received with each recipe are wrapped in aluminium foil for identification. Another survey is directed towards households in the same communes in semi-structured and focus group settings to find out the population's level of knowledge about Vernonia amygdalina in the treatment of liver diseases.

\subsection{Statistical Processing of Data}

The results obtained from ethnobotanical and household surveys are entered into Excel 2013. The XLSTAT 2019 software has allowed us to perform a descriptive analysis of the data obtained

\section{Results}

The results of ethnobotanical surveys among herbalists and in households allowed us to appreciate the medicinal plants made available to the population for the treatment of liver diseases in Southern Benin and to verify the level of knowledge of this same population on the use of Vernonia amygdalina leaves. The ethnobotanical survey is being carried out in 19 markets and 4 sites selling medicinal plants in three communes of Southern Benin; Cotonou, Abomeycalavi, and Ouidah. The household survey was conducted in the same communes mentioned above. The results of the ethnobotanical survey among herbalists are summarized in the table 1 .

Table 1. Descriptive statistics of medicinal plants identified during the survey.

\begin{tabular}{llll}
\hline Statistics & Species & Families & Organs \\
\hline Nb. Of observations & 88 & 88 & 88 \\
Mode & Bridelia ferruginea & Rubiaceae & Root \\
Mode (effective) & 10 & 16 & 47 \\
\hline
\end{tabular}

The number of observations after the survey is 88. The plant species with a high population is Bridelia ferruginea of the family Euphorbiaceae (Figure 3). On the other hand, the family Rubiaceae is more represented (Figure 4). 


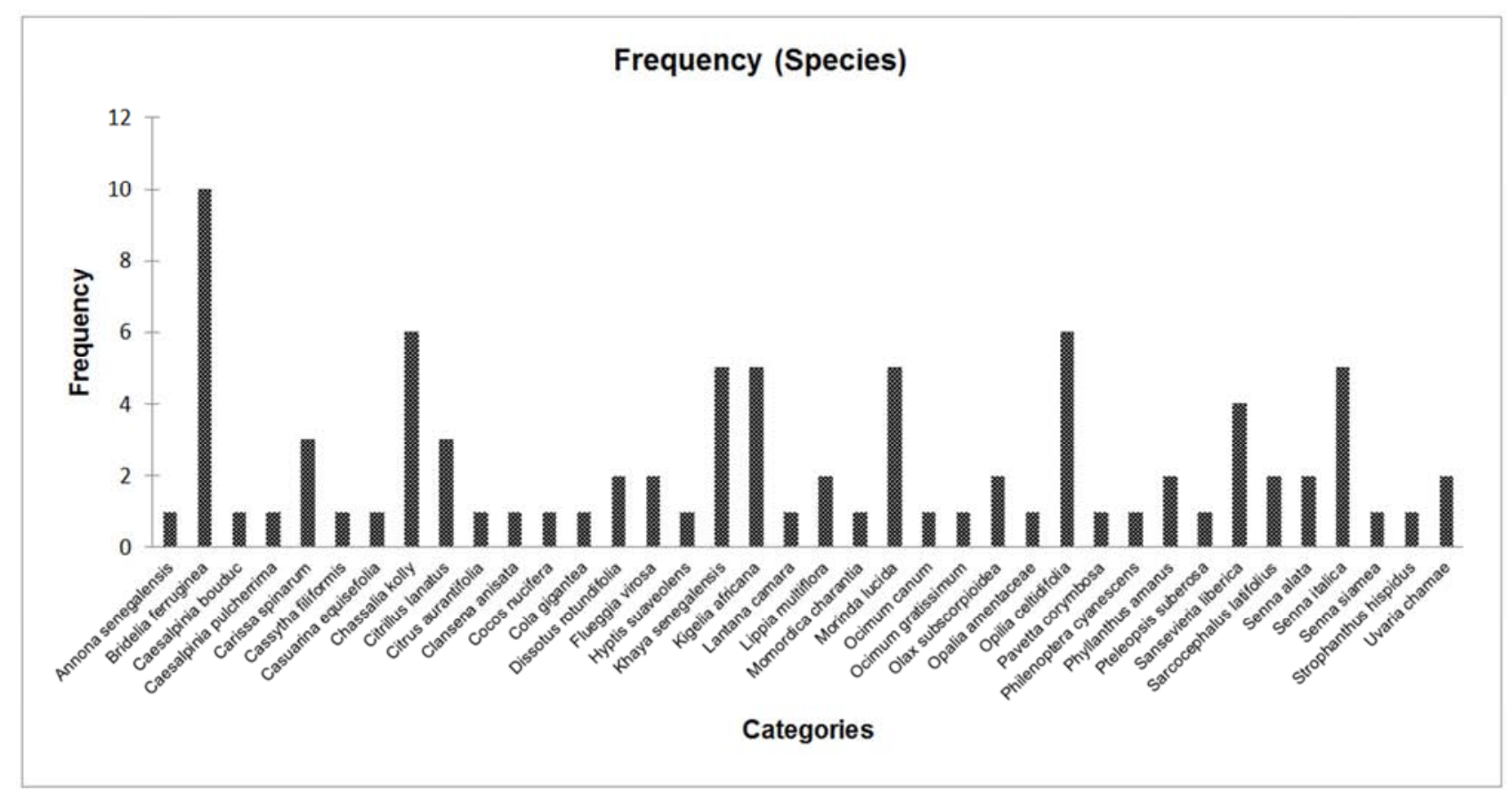

Figure 3. Number of species according to modality.

The species represented belong to twenty families (Figure 4).

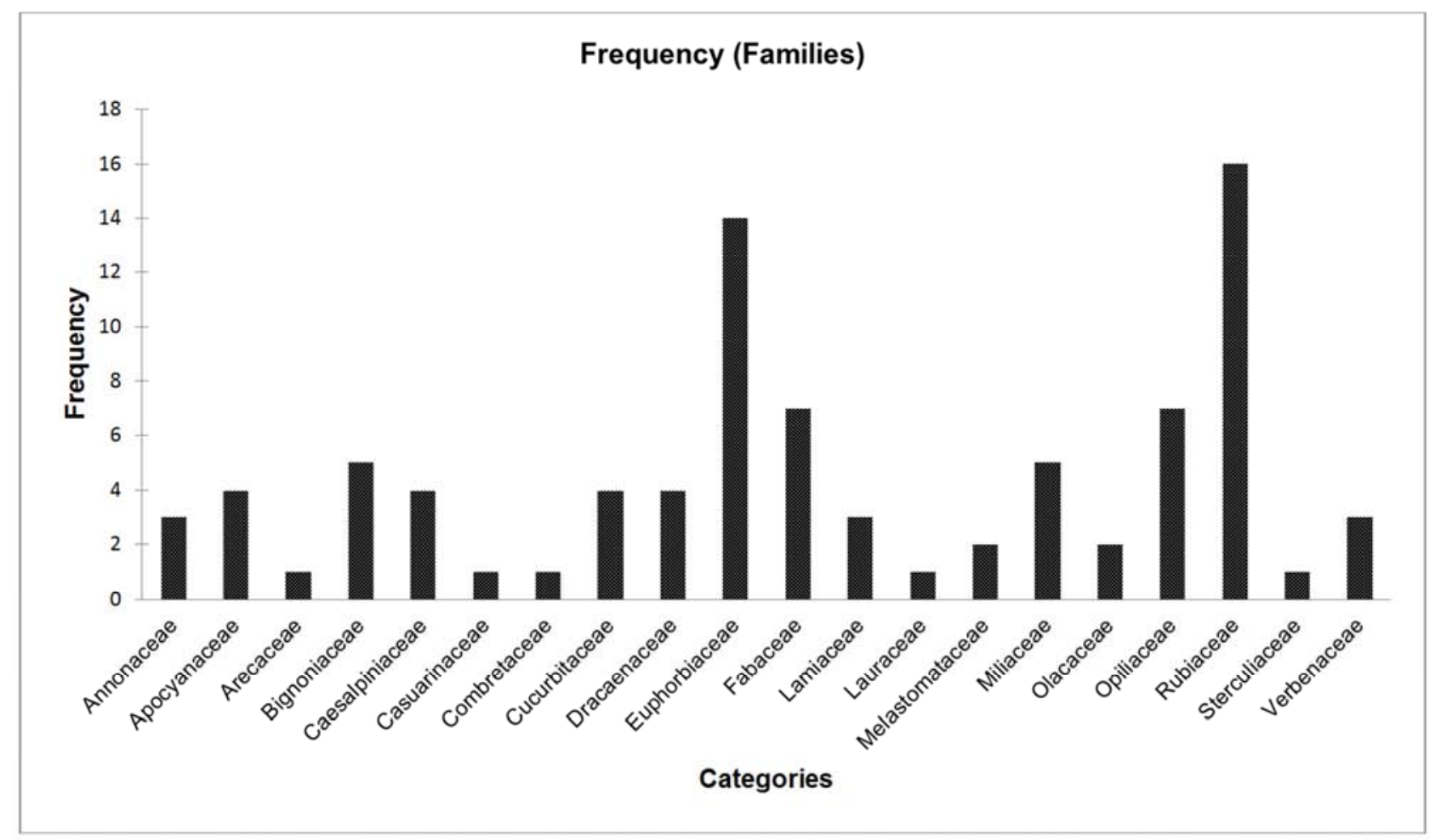

Figure 4. Number of families according to their modality.

In the course of the investigation, various parts of the medicinal plant were proposed in the preparation of traditional medicine remedies for the treatment of liver diseases. Roots account for $47 \%$, leaves $25 \%$, bark $12 \%$, leafy stems $1 \%$ and fruits $3 \%$ (Figure 5). This high representation of roots in the recipes proposed does not guarantee the protection of flora for sustainable development. 


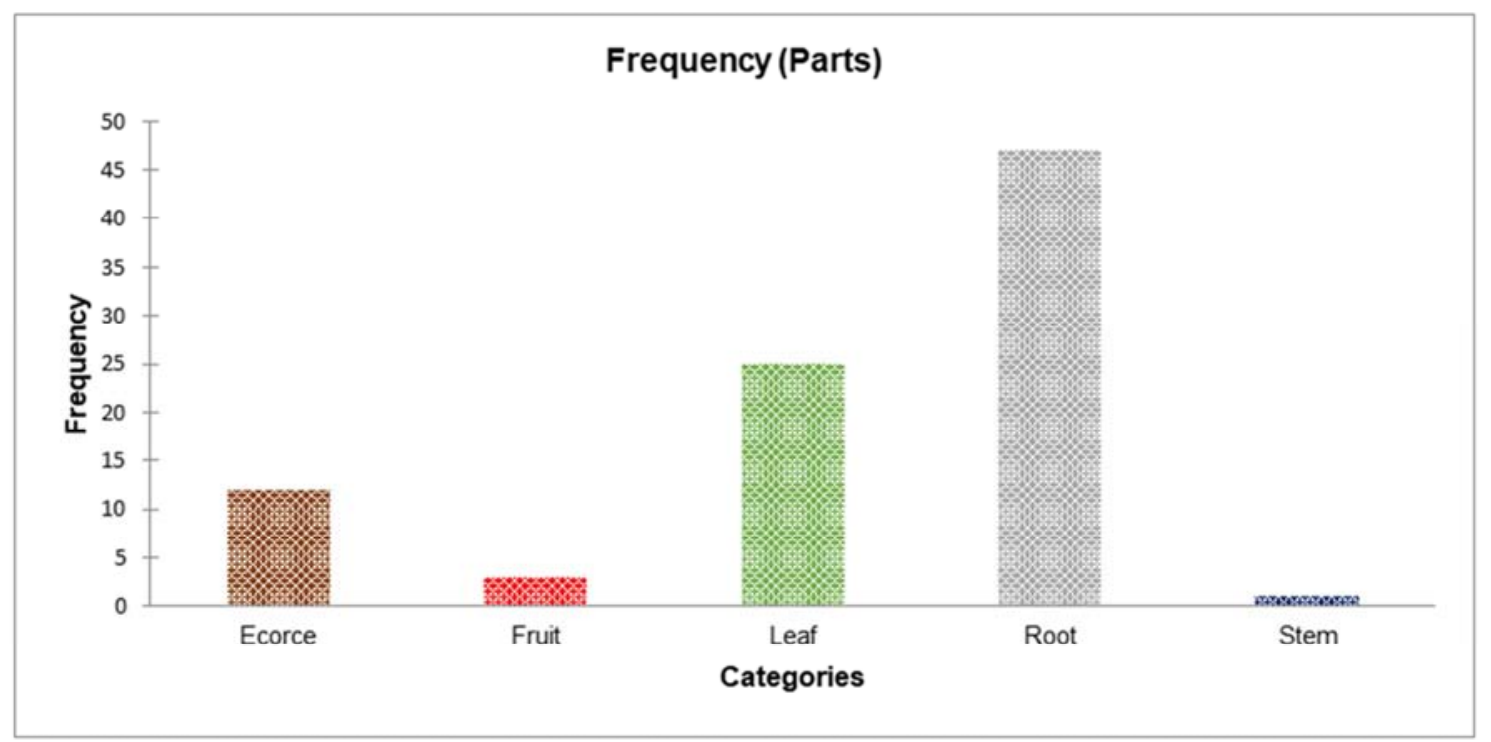

Figure 5. Number of organs of the plants harvested according to their modality.

A second survey is directed towards households on their knowledge of Vernonia amygdalina. A total of 552 respondents answered our questions. Regarding the use of Vernonia amygdalina, $64 \%$ of the staff use it in nutrition against $36 \%$ in phytotherapy (figure 6). A very high proportion of the population obtains its supplies in urban areas (68\%), compared to $19 \%$ in market gardening sites, and 13\% in remote fields (figure 7).

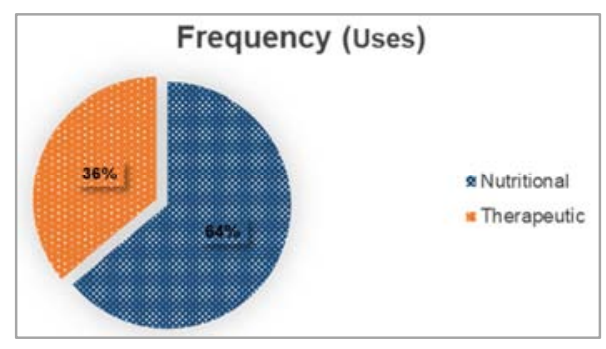

Figure 6. Uses of Vernonia amygdalina.

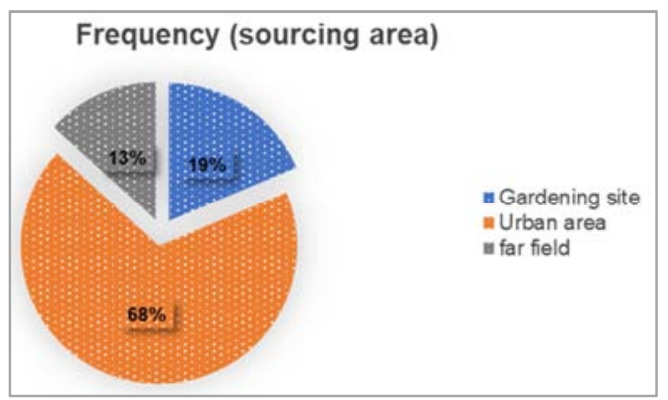

Figure 7. Vernonia amygdalina Sourcing Area.

The leaves of Vernonia amygdalina are very little known in phytotherapy according to the survey conducted among herbalists. The results of the survey carried out among the population confirm this. $35 \%$ claim to have no idea of its use in the treatment of pathologies, $21 \%$ use it to treat intestinal affections, $18 \%$ use it to treat malaria, $13 \%$ to treat oral affections, $12 \%$ for other unspecified pathologies and only $1 \%$ for the treatment of hepatic affections (figure 8).

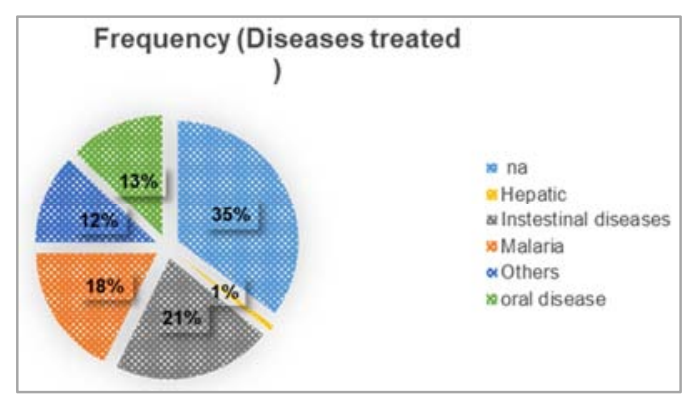

Figure 8. Diseases treated with Vernonia amygdalina.

The frequency of use in nutrition and herbal medicine shows the same trends. Twice-weekly use is preferred in both cases, followed by once a week (Figures 9 and 10).

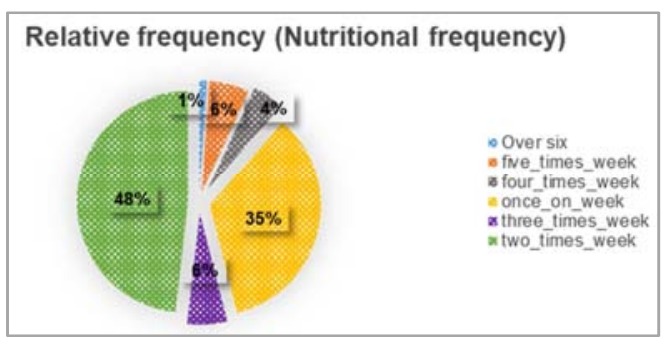

Figure 9. Use of Vernonia amygdalina in nutrition.

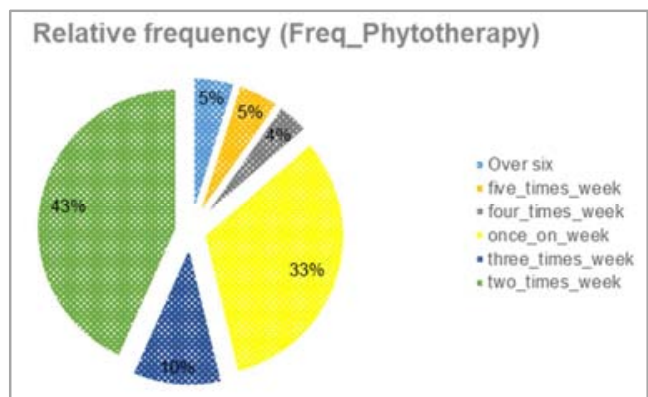

Figure 10. Use of Vernonia amygdalina in phytotherapy. 


\section{Discussion}

The ethnobotanical survey of herbalists has shown that roots are more appropriate in recipes than other parts of the plant. These results are contrary to those of [5] who showed that leaves are cited more than other plant organs. The best represented family is that of Rubiaceae. [16] showed that the best represented families in the treatment of liver diseases are Asteraceae, Euphorbiaceae and Fabaceae. Many medicinal plants are mentioned only once. Bridelia ferruginea is the most representative $11.90 \%$. The organ harvested is the root. [17] showed that the leaves of Bridelia ferruginea are hepatoprotectors in second position after the leaves of Vernonia amygdalina. During his survey on the use and effect of herbal medicines in patients suffering from liver diseases hospitalized at the Department of Medicine and Hepatogastroenterology of the University Hospital Center (CHU) of Cocody in Côte d'Ivoire [16] showed that the leaves of Vernonia amygdalina are cited among the most widely used medicinal plants. [18] conducted a census of medicinal plants that fight liver diseases across Africa. Morinda lucida is cited in many African countries as a medicinal plant used in the traditional treatment of liver diseases. It is one of the nine most representative plant species in our study. Cochlospermum tintorium of the family Cochlospermaceae; Entada africana of the family Mimosaceae; Combretum micranthum of the family Combretaceae were cited in the work of [19] as medicinal plants used in the traditional treatment of hepatitis B in Mali. $[20,21]$ showed that Desmodium adscendens of the Fabaceae family, Phyllanthus amarus of the Euphorbiaceae family have anti-hepatotoxic activities. Several plant species are cited as anti-hepatotoxic in different countries. Plants whose leaves are effective in the prevention and treatment of hepatitis must be favoured in order to perpetuate rare species. The leaves of Vernonia amygdalina are confirmed by the work of [9] as anti-hepatotoxic. The population lacks information about its potential in phytotherapy. A management of popularization is important for the knowledge of Vernonia amygdalina for its therapeutic virtues. The supply sites must be air-conditioned in order to limit the risks of contamination by toxic metals which can hinder their effectiveness. A large proportion of the population obtains its supplies in built-up areas, but roadsides must be avoided to limit the risk of contamination by toxic metals. The work of [22] showed that the leaves of Vernonia amygdalina are contaminated by toxic metals on market gardening sites like other vegetables. Food products from urban areas are not spared by this contamination as confirmed by the work of [23] in the province of Katanga in DR Congo. The frequency of use must be reviewed in the case of treatment of pathologies in order to guarantee a cure without negative impact depending on the dose.

\section{Conclusion}

The ethnobotanical survey has allowed to take stock of the knowledge of Vernonia amygdalina in nutrition, phytotherapy and places of supply. The plant is very little known in phytotherapy and by the population in the treatment of liver diseases. All looks and recipes are oriented towards the sensitive parts (roots and bark) of rare medicinal plants that are not easy to cultivate. This allows a speculation of recipes with herbalists. A management must be made for the popularization of these medicinal plants easy to reproduce in order to redirect the eyes of the population and facilitate the conservation of the flora. Supply sites such as market gardening sites and towns occupy an important place. Therefore, monitoring is necessary for the reasonable use of inputs, compost and other soils that can increase the contamination of plants by toxic metals.

\section{References}

[1] Sehonou J, Kodjoh N, Sake K, Mouala C (2010). Hepatic cirrhosis in Cotonou (Republic of Benin): clinical aspects and factors related to death. Med. Trop. 70, 4. 375-378.

[2] Mégarbane B, Deye N, Baud F (2007). Toxic hepatitis: Mechanisms of toxicity and specific pharmacological agents. Journal homepage, 16, 632-642.

[3] Labbe G, Pessayre D, Fromenty B (2008). Drug-induced liver injury through mitochondrial dysfunction: mechanisms and detection during preclinical safety studies. Fundamental and clinical pharmacology; 22, 4, 335-353.

[4] WHO (2002). WHO Strategy for Traditional Medicine for 2002-2005. WHO/EDM/TRM/2002. Genève Suisse, pp 26-30.

[5] Guinnin FDF, Sacramento TI, Sezan A, Ategbo JM (2015). Ethnobotanical study of medicinal plants used in the traditional treatment of viral hepatitis $\mathrm{B}$ and $\mathrm{C}$ in some departments of Benin. International Journal of Biological and Chemical Sciences. 9 (3) 1354-1366.

[6] Mangambu M., Van Diggelen R., Mwanga Mwanga JC., Ntahobavuka H. Malaisse F. \& Robbrecht E. (2012). Ethnopteridological study, extinction risk assessment and conservation strategies in the vicinity of the Kahuzi Biega National Park in D. R. Congo. International Journal of Tropical Ecology and Geography 36 (1/2), pp 137-145.

[7] Yeap SK, Ho YW, Beh BK, Liang WS, Ky H, Yousr AHN and Alitheen NB (2010). Vernonia amygdalina, an ethnoveterinary and ethnomedical used green vegetable with multiple bioactivities. Journal of Medicinal Plants Research. 4 (25), pp. 2787-2812.

[8] Atangwho IJ, Edet EE, Uti DE, Obi AU, Asmawi ZM, Ahmad M (2012). Biochemical and histological impact of Vernonia amygdalina supplemented diet in obese rats Saudi Journal of Biological Sciences 19, 385-392.

[9] Iroanya OO, Adebesin OA, Okpuzor J (2014). Evaluation of the Hepato and Nephron-Protective Effect of a Polyherbal Mixture using Wistar Albino Rats. Journal of Clinical and Diagnostic Research. 8 (6): HC15-HC21.

[10] Kamatenesi-Mugisha MM, Oryem-Origa H (2007). Medicinal plants used in some gynaecological morbidity ailments in western Uganda. African Journal of Ecology, 45 (Suppl. 1). 34-40. 
[11] Abuti JRS, Kukunda CB, Waako PJ (2010). Medicinal plants used by traditional medicine practitioners in the treatment of tuberculosis and related ailments in Uganda. Journal of Ethnopharmacology, 127, 130-136.

[12] Tilahun T (2009). Ethnobotanical study of knowledge and medicinal plants use by the people in Dek Island in Ethiopia. Journal of Ethnopharmacology, 124, 69-78.

[13] Africa Council (2006). Monograph of the commune of Cotonou $47 \mathrm{p}$.

[14] Africa Council (2006). Monograph of the commune of Abomey-Calavi72p.

[15] Africa Council (2006). Monograph of the commune of Ouidah. 44p.

[16] Kande B, Yao K, Allah-Kouadio E, Kone MW (2018). Survey on the use and effect of herbal medicines in hepatic patients hospitalized at the Medicine and Hepatogastroenterology Department of the University Hospital Center (CHU) of Cocody in Côte d'Ivoire. Journal of Applied Biosciences. 130: 13220-13231.

[17] Adetutu A and Olorunnisola OS. (2013). Hepatoprotective Potential of Some Local Medicinal Plants against 2Acetylaminoflourene-Induced Damage in Rat. Journal of Toxicology. $5 \mathrm{p}$.

[18] Bitsindou M, Lejoly J et Van Essghe K (1993). Plants used against liver diseases in traditional African medicine.
Proceedings of the 2nd EuropCen Colloquium of Ethnopharmacology and Island International Conference of Ethnomedicine, Heidelberg, 24-27.

[19] Djiguida M (2005). Evaluation of three recipes in the traditional treatment of hepatitis B in Mali. Faculty of Medicine, Pharmacy and Odonto -Stomatology. University of Bamako. 94p.

[20] Tubéry P, Ragot J, lagarde P, Authier-derivaux d, Pidoux M, Rasolohery C, Bourdy G (2015). Composition and Functional Properties of Vernonia amygdalina Vegetable Leaf Protein Concentrates Greener. Journal of Agricultural Sciences. 3 (3), pp. 204-210.

[21] Ott M, Thyagarajan SP, Gupta S (1997). Phyllanthus amarus suppresses hepatitis B virus by interrupting interactions between HBV enhancer I and cellular transcription factors. European Journal of Clinical. Investigation. 27 (11), 908-915.

[22] Yehouenou EAP, Soton A, Azocli D, Acakpo H, Boco M, Fourn L, Houinsa D, Keke JC et Fayomi B, (2010). Contamination of soil, water and market garden produce by toxic substances and heavy metals at the Houéyiho site (Cotonou) in the Republic of Benin. Int. J. Biol. Chem. Sci. 4 (6): $2160-2168$.

[23] Kalonda MD, Tshikongo AK, koto KKF, Busambwa KC, Bwalya KY, Cansa MH, Tambwe KJL, Kalala LZ, Otshudi AL (2015). Profile of heavy metals contained in commonly consumed food crops in some mining areas of Katanga Province. Journal of Applied Biosciences 96: 9049-9054. 